Brook, R. W., J. O. Leafloor, K. F. Abraham and D. C. Douglas 2015. Density dependence and phenological mismatch: consequences for growth and survival of sub-arctic nesting Canada Geese. Avian Conservation and Ecology 10(1): 1. http://dx.doi.org/10.5751/ACE-00708-100101

Copyright (C) 2015 by the author(s). Published here under license by the Resilience Alliance.

Research Paper

\title{
Density dependence and phenological mismatch: consequences for growth and survival of sub-arctic nesting Canada Geese
}

\author{
Rodney W. Brook ${ }^{1}$, James O. Leafloor ${ }^{2}$, Kenneth F. Abraham ${ }^{1}$ and David C. Douglas ${ }^{3}$ \\ ${ }^{1}$ Ontario Ministry of Natural Resources and Forestry, ${ }^{2}$ Environment Canada, Canadian Wildlife Service, ${ }^{3}$ U.S. Geological Survey \\ Alaska Science Center
}

\begin{abstract}
The extent to which species are plastic in the timing of their reproductive events relative to phenology suggests how climate change might affect their demography. An ecological mismatch between the timing of hatch for avian species and the peak availability in quality and quantity of forage for rapidly growing offspring might ultimately affect recruitment to the breeding population unless individuals can adjust the timing of breeding to adapt to changing phenology. We evaluated effects of goose density, hatch timing relative to forage plant phenology, and weather indices on annual growth of pre-fledging Canada geese (Branta canadensis) from 1993-2010 at Akimiski Island, Nunavut. We found effects of both density and hatch timing relative to forage plant phenology; the earlier that eggs hatched relative to forage plant phenology, the larger the mean gosling size near fledging. Goslings were smallest in years when hatch was latest relative to forage plant phenology, and when local abundance of breeding adults was highest. We found no evidence for a trend in relative hatch timing, but it was apparent that in early springs, Canada geese tended to hatch later relative to vegetation phenology, suggesting that geese were not always able to adjust the timing of nesting as rapidly as vegetation phenology was advanced. Analyses using forage biomass information revealed a positive relationship between gosling size and per capita biomass availability, suggesting a causal mechanism for the density effect. The effects of weather parameters explained additional variation in mean annual gosling size, although total June and July rainfall had a small additive effect on gosling size. Modelling of annual firstyear survival probability using mean annual gosling size as an annual covariate revealed a positive relationship, suggesting that reduced gosling growth negatively impacts recruitment.
\end{abstract}

\section{Dépendance à la densité et désynchronisation phénologique : conséquences sur la croissance et la survie des Bernaches du Canada nichant en milieu subarctique}

RÉSUMÉ. Le degré de plasticité que montrent les espèces dans la chronologie de leurs activités de reproduction en fonction de la phénologie nous en apprend sur la façon avec laquelle les changements climatiques pourraient affecter leur démographie. Un décalage entre la période d'éclosion des oiseaux et le pic de disponibilité des ressources alimentaires, tant en quantité qu'en qualité, pour les jeunes en croissance, peut ultimement perturber le recrutement dans la population nicheuse, à moins que les individus ne soient capables de synchroniser leur reproduction avec la phénologie changeante. Nous avons évalué les effets de la densité des bernaches, de la période d'éclosion relativement à la phénologie des plantes recherchées pour l'alimentation, et de paramètres météorologiques sur la croissance annuelle de Bernaches du Canada (Branta canadensis) avant leur premier envol, de 1993 à 2010, sur l'île Akimiski au Nunavut. Nous avons observé des effets de la densité et la période d'éclosion relativement à la phénologie des plantes; plus les !ufs éclosaient tôt relativement à la phénologie des plantes, plus la taille moyenne des oisons au moment de leur premier envol était grande. La taille des oisons était la plus petite les années où l'éclosion était la plus tardive relativement à la phénologie des plantes et les années où le nombre d'adultes était le plus élevé localement. Aucune tendance dans la période relative d'éclosion n'a été observée, mais il était évident qu'en présence d'un printemps hâtif, les oisons avaient tendance à éclore plus tard par rapport à la phénologie des plantes, ce qui laissait croire que les bernaches n'étaient pas toujours capables d'ajuster rapidement la chronologie de leurs activités dans les cas où la phénologie des plantes était devancée. L'analyse des données relatives à la biomasse des plantes a mis au jour l'existence d'une relation positive entre la taille des oisons et la disponibilité de la biomasse par individu, ce qui donne à penser qu'un mécanisme causal existe quant à l'effet de la densité des bernaches. Les effets des paramètres météorologiques ont permis d'expliquer une partie additionnelle de la variabilité de la taille moyenne annuelle des oisons, quoique les précipitations totales en juin et juillet ont eu un léger effet positif sur la taille des oisons. La modélisation de la probabilité de survie des oisons au cours de la première année, effectuée en utilisant leur taille moyenne annuelle comme covariable annuelle, a révélé une relation positive, ce qui semble indiquer qu'une croissance réduite des oisons a un effet négatif sur le recrutement.

Key Words: Branta canadensis; Canada goose; climate; density dependence; ecological mismatch; growth; plant phenology; survival 


\section{INTRODUCTION}

For geese, any constraint affecting food availability and quality, as well as its uptake and processing, can have an impact on the rate of gosling growth. Indeed, the per capita availability of high quality forage affects gosling growth rates (Lindholm et al. 1994, Sedinger et al. 2001, Lake et al. 2008, Fondell et al. 2011), which in turn could negatively affect components of population dynamics (Schmutz 1993, Shorrocks et al. 1998, Cooch et al. 2001, Nicolai et al. 2014). Density of conspecifics and ecologically similar species can also limit forage availability through exploitation and interference competition (Loonen et al. 1997, Sedinger et al. 1998, Schmutz and Laing 2002). This can reduce food intake below optimum rates for goslings, especially during the first few weeks after hatch, when skeletal growth is fastest (Leafloor et al. 1998).

A complex relationship may exist between population density and forage availability. For example, foraging by geese can increase plant productivity through a feedback mechanism in which moderately grazed vegetation can produce higher quality forage for longer compared to plants that are not grazed (Harwood 1977, Bazely and Jefferies 1986, 1989, Hik and Jefferies 1990, Person et al. 2003). Similarly, grazing may change the phenotype of some species from a low quality to a high quality forage, thus increasing available feeding habitat (Person et al. 2003, Fondell et al. 2011). However, overgrazing is detrimental (Kuijper et al. 2009) and can result in generally lower gosling growth rates (Cooch et al. 1991a, $b$, Williams et al. 1993, Sedinger et al. 2001). Thus, densities of geese below a threshold may actually improve foraging conditions, but higher densities are more likely to inhibit gosling growth through exploitive competition (Bazely and Jefferies 1997).

Average hatch timing for geese generally coincides with the spring flush of growth of forage species so that newly hatched goslings can take advantage of the high nutritional content and digestibility of new plant growth (Cargill and Jefferies 1984, Sedinger and Raveling 1986). The seasonal decline in forage quality and negative consequences of hatching relatively late within a year compared with conspecifics suggest that differences in hatch dates of as little as a week can result in detectable declines in gosling growth (Cooch et al. 1991a, Sedinger and Flint 1991, Lindholm et al. 1994, Lepage et al. 1998). Person (2001) demonstrated experimentally that late hatched goslings could not compensate for poor forage quality by increasing intake rates and were lighter at 31 days posthatch compared to those that hatched earlier. Therefore, optimizing the time of hatch so that goslings can graze on favorable forage could convey a fitness advantage by facilitating maximum gosling size, because larger size can equate to higher survival and greater fitness (Williams et al. 1993, Sedinger et al. 1995, Hill et al. 2003, Sedinger and Chelgren 2007). Hatching before or after the period of peak forage quality and abundance can be detrimental to gosling growth and may also exacerbate the potential consequences of competition.

Much focus has recently been placed on evidence that some species are not keeping pace with the general advancement in the phenology of the forage species on which they rely (Visser and Both 2005, Donnelly et al. 2011, Dunn et al. 2011, Saino et al. 2011, Cleland et al. 2012). This is often referred to as an ecological mismatch, which occurs when a synchronous partnership becomes disjunct in time or space, resulting in a trophic decoupling (Stenseth and Mysterud 2002). Projections of climate change in Arctic and Subarctic regions suggest increased annual variability and a general advancement in spring phenology (Schwartz et al. 2006). For herbivores, the timing of reproduction and how well it matches the timing of optimum forage availability and quality can be an important determinant of offspring survival and future reproduction (Sedinger and Raveling 1986).

A disparity between the timing of hatch and timing of optimum nutritional forage availability is not likely detrimental within some bounds of normal variation. However, increasing variation or a significant directional change in a trophic synchrony may have consequences on the growth and population dynamics of Subarctic nesting geese. Canada Geese often arrive before nesting and foraging sites are free of ice and snow in Subarctic regions and may begin nesting before most plants begin to grow. Egg laying and incubation take about 32 days (e.g., 5 days of egg laying, followed by 27 days of incubation), so Canada Goose nest timing must be synchronized with peak nutrient availability well in advance, likely by responding to the same factors that determine plant growth, such as snow cover or ambient temperature (Dickey et al. 2008). Given the range of latitudes where Canada Geese nest in North America, i.e., between $30^{\circ} \mathrm{N}$ and $60^{\circ} \mathrm{N}$ latitude, (Mowbray et al. 2002), and the associated range in phenology of their forage plants, it is likely that they are flexible in altering their annual date of nest initiation. Nonetheless, any directional change that occurs between the timing of nesting and the onset of plant growth could still result in a phenological mismatch, which may affect gosling growth.

Numbers of Canada Geese on Akimiski Island, Nunavut declined from about 76,000 birds in 1985 to about 20,000 birds in 1993, a period also with a decline in direct recovery rates, i.e., the proportion of banded birds shot and reported during the hunting season following banding, of banded juvenile geese (Leafloor et al. 1996; Fig. 1). The decline in direct recovery rates was only for goslings from Akimiski Island and not adult geese from the same area, or goslings from adjacent breeding areas that shared the same migration and wintering areas (Leafloor et al. 1996). These results suggest that late summer mortality might have occurred after goslings were banded just before fledging, consistent with the effects of chronic malnutrition, and could be responsible for the low recovery rates of goslings banded on Akimiski Island (Leafloor et al. 2000, Patton 2001, Hill et al. 2003).

The population of Canada Geese nesting on Akimiski Island has varied considerably in size since 1993, and our long term study of nesting ecology and survival provided an opportunity to evaluate density-dependent effects on gosling growth and first-year survival. At the same time, we were interested in exploring the hypothesis that warmer, earlier springs could lead to a mismatch between the timing of hatch and forage plant availability, which could have negative effects on gosling growth and survival. We measured gosling size and modeled annual variation in gosling growth using environmental and population covariates as direct and indirect measures of variation in food abundance and quality. Specifically, we tested for effects of population density, hatch timing relative to forage plant phenology, and additive effects of weather or climate variables on gosling growth. We further examined the consequences of variation in mean gosling size on the probability of first-year survival. Finally, we related variation in gosling growth and survival to forage availability for Canada Geese nesting on Akimiski Island, Nunavut. 
Fig. 1. Harvest rates, i.e., banded birds shot and reported by hunters in the hunting season immediately following banding corrected for reporting rate, of Canada Geese banded as juveniles on Akimiski Island, Nunavut (closed diamonds, left Y-axis), and number of nesting (number of indicated breeding birds) and nonbreeding (geese counted in groups of $>3$ birds) Canada Geese on Akimiski Island, Nunavut, from 1985-2010, based on aerial surveys (see Leafloor et al. 1996 for details; open squares, right Y-axis).

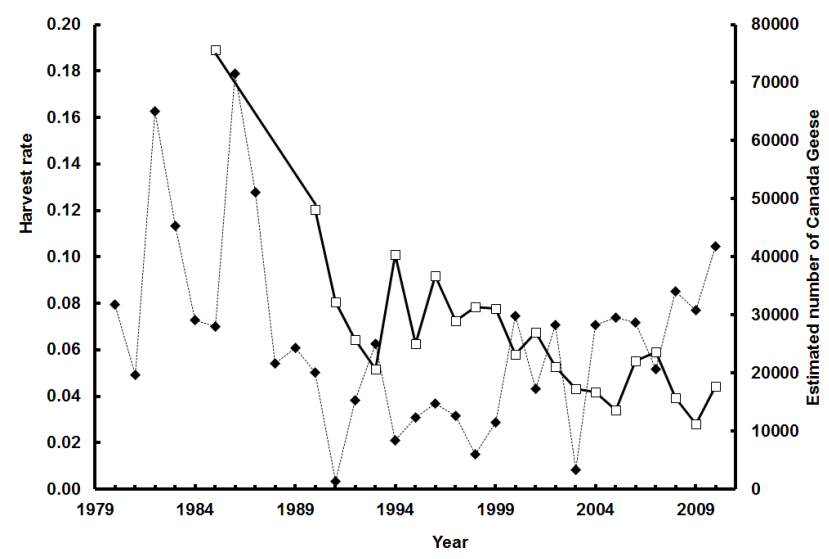

\section{METHODS}

We searched for nests of Canada Geese in coastal areas of Akimiski Island, Nunavut ( $\left.53^{\circ} 0^{\prime} 47^{\prime \prime} \mathrm{N}, 81^{\circ} 19^{\prime} 16^{\prime \prime} \mathrm{W}\right)$ once egg laying was thought to be complete (1993-2002) or during the last two weeks of incubation (2003-2010), marking each nest with a metal stake and flagging tape placed about $15 \mathrm{~m}$ north of each nest (Leafloor et al. 2000). Eggs were marked with the nest number and a number indicating probable laying sequence based on amount of staining (Raveling and Lumsden 1977). Date found, clutch size, incubation stage using flotation method (Walter and Rusch 1997), and location were recorded. We attempted to revisit each nest daily during the predicted hatching period until eggs hatched or nest fate was determined. Any new nests found during the hatch period were also marked and monitored. Goslings from pipped eggs and those that had hatched were tagged with individually numbered size 1 Monel web tags. We returned daily to each nest to determine fate of all tagged goslings and any unhatched eggs (Leafloor et al. 2000).

\section{Gosling body size}

Groups of flightless geese were captured 5-8 weeks after peak hatch, when goslings were 29-61 days old, in coastal habitats using a helicopter drive technique (Leafloor and Rusch 1997). We attempted to catch whole flocks of adult geese with their goslings whenever possible and tried to avoid flocks that were too large to be safely maintained in the nets or that appeared to have few or no goslings. All goslings captured were fitted with standard aluminum leg bands and web-tagged goslings were weighed with a spring scale to the nearest $\pm 1 \mathrm{~g}$, and skull length, culmen 1 , and tarsus length $( \pm 0.1 \mathrm{~mm})$ were measured following Dzubin and Cooch (1992).
To correct for body size differences among gosling ages and sexes, we used growth curve equations calculated from a previous study of goslings that were raised in captivity on high quality diets, from Akimiski Island (Leafloor et al. 1998). We assumed that captive goslings grew at the maximum rate possible, and that growth was not limited by conditions of captivity, because goslings were fed high protein diets ad libitum, and grew to be larger than adult birds found on Akimiski Island (Leafloor et al. 1998). We subtracted predicted skull or culmen measurements of captive goslings from those of wild goslings of the same age and sex to obtain pseudo residuals, which represented a relative measure of size that was independent of gosling age and sex (sensu Sedinger and Flint 1991). We used a principal components analysis (SAS Institute 2003; PROC PRINCOMP) to reduce skull and culmen pseudo residuals to a single value using the first principal component scores (explaining $88 \%$ of the total variance) and added a constant (28) to make all values positive. Thus, goslings with the smallest pseudo residual (hereafter gosling size) values were those with the slowest growth relative to the captive bird reference curves. We found that this method accounts for the nonlinear growth and the relatively wide range of ages at which we measured goslings. We tested for annual differences in gosling size using gosling pseudo residuals with a random effect of brood ID (SAS Institute 2003; PROC GLIMMIX).

\section{Factors affecting gosling size}

We compared relative performance among the candidate sets using Akaike's Information Criterion corrected for small sample sizes $\left(\mathrm{AIC}_{\mathrm{c}}\right.$ ) and $\mathrm{AIC}_{\mathrm{c}}$ model weights $\left(w_{i}\right.$; Burnham and Anderson 2002). First, we compared a set of generalized linear mixed models (SAS Institute 2003; PROC GLIMMIX), which tested for effects of density, hatch timing relative to forage plant phenology, and weather on gosling size. We controlled for nonindependence in size among gosling siblings by including brood ID as a random variable. A population estimate (POPEST: number of Canada Goose pairs estimated from an annual aerial spring survey of Akimiski Island; Leafloor et al. 1996) and the annual number of successful Canada Goose nests in a standardized geographic area (SUCCNEST) were used as annual population density indices. We included candidate models, which also included a weather variable, to determine the additive effect, if any, on gosling size. Finally, we did a post hoc analysis using variables from the best model from the previous step on a smaller dataset (fewer years) to determine the effect of more direct measures of the relative abundance of forage on gosling size.

In the first step, we used Normalized Difference Vegetation Index (NDVI) to provide a means for assessing forage quality (Ryan et al. 2012) by using remotely sensed visible and near-infrared light reflected by vegetation (Tucker 1979). To quantify vegetation phenology, we used an 18-year NDVI time series to annually estimate the day of year when $50 \%$ of the annual maximum NDVI was attained, i.e., $\mathrm{NDVI}_{50}$ within the Akimiski Island reference area. $\mathrm{NDVI}_{50}$ is related to the date of peak nitrogen concentration in plants and can provide a reliable measure of annual variation in the timing of the availability of high quality forage for geese (Doiron et al. 2013). We assumed the index for all vegetation was a suitable index for goose forage species. We investigated the relationship between mean hatch timing and forage plant phenology derived from $\mathrm{NDVI}_{50}$ using linear regression. We 
indexed timing of hatch relative to vegetation phenology by subtracting the date of $\mathrm{NDVI}_{50}$ from mean annual hatch date each year; larger values of TIMING represented years when hatching occurred relatively late compared to vegetation phenology. We also assessed a quadratic relationship between gosling size and TIMING, predicting that there would be a negative effect on gosling size for goslings that hatched either early or late relative to the index of forage plant phenology.

\section{Normalized Difference Vegetation Index (NDVI)}

An 18-year time series (1993-2010) of $\mathrm{NDVI}_{50}$ was constructed from 2 data sources, each comprised of daily global NDVI mosaics on a 0.05 -degree pixel-resolution grid: (1) the Long Term Data Record Version 3 collected by the Advanced Very High Resolution Radiometer (AVHRR), 1982-1999 (http://ltdr. nascom.nasa.gov); and (2) the Earth Science Data Record of preprocessed NDVI collected by the Moderate Resolution Imaging Spectroradiometer (MODIS), 2000-2010 (http://vip. arizona.edu). The AVHRR NDVI values were scaled to attain continuity with MODIS NDVI (Miura et al. 2006) using satellitespecific, top-down equations documented at the vip.arizona.edu website. Maximum-value NDVI composites (Holben 1986) were produced for $\sim 10$-day periods (3 per month; days 01-10, 11-20, and 21+). MODIS pixels were excluded from compositing if their solar zenith angle was $>75^{\circ}$ or their satellite view angle was $>$ $42^{\circ}$. Date of the maximum NDVI for each pixel in each composite period was retained. AVHRR composite periods with entirely missing data $(n=10)$ were filled by averaging the preceding and subsequent years and similarly for MODIS $(n=14)$. Only 4 of the 24 missing composite periods occurred during the months of March through August.

Data were extracted from the NDVI composites for 32 terrestrial pixels, which extended across northeastern Akimiski Island. For each pixel, periods of implausible drops in NDVI usually caused by persistent cloud cover were smoothed by linearly interpolating between the NDVI and pixel-dates of adjacent periods. NDVI values $<0.10$ were assigned 0.10 to disregard inconsequential noise. Occasional greenness anomalies before the growing season were ignored by setting NDVI $=0.10$ until at least 10 cumulative thaw-degree days had been attained (beginning 1 January and using a $-2^{\circ} \mathrm{C}$ threshold). Thaw degrees were tabulated using average daily $2 \mathrm{~m}$ air temperature data from the NCEP/NCAR Reanalysis (Kalnay et al. 1996). Each annual NDVI phenology curve was manually inspected and the thaw-degree-day threshold was adjusted if the temperature constraint showed any indication of misrepresenting onset of the growing season (once in 2010). At each pixel, daily NDVI estimates were linearly interpolated between the dates of each composite period, after which a time series of daily median NDVI within the study area $(n=32$ pixels) was calculated for each year, to construct annual NDVI phenology curves. For each year, amplitude of the median NDVI phenology curve was calculated as the difference in NDVI between a 29-year average winter baseline (January) NDVI and the annual daily maximum NDVI. The date (day of year) when $50 \%$ of the annual NDVI amplitude was attained was extracted as a metric relating to the timing of vegetation growth for the respective year.
We tested for additive effects of weather on gosling size. We hypothesized that weather might affect gosling growth by affecting forage quality and abundance. To test for the effects of precipitation on gosling body size, we first assessed variables describing total precipitation for different periods, i.e., for the month of June, for the first two weeks following hatch, and for the period from mean hatch date to the mean date of capture. There was significant and nearly equal correlation among these variables so, to simplify analysis, we selected a single variable that was most highly correlated with gosling size, i.e., total June and July rainfall. This variable also made intuitive sense because there was likely some carry over effects of precipitation on forage plant species prior to hatch. We predicted that a positive relationship exists between total precipitation and forage quality and abundance, which would thus positively affect gosling growth rates. We also recognized a potential negative effect of precipitation caused by thermal stress on goslings before they are fully feathered and endothermic (Schmutz et al. 2001). Rain data were either directly measured on Akimiski Island (2004-2010) using a tipping bucket rain gauge or by calculating a mean of daily precipitation data from Environment Canada meteorological stations (Fort Albany, East Main, Kuujjuarapik, La Grand, Moosonee, Peawanuck) for the period 1993-2003. The daily mean average was weighted by the inverse of the distance of each station to Akimiski Island.

Finally, we conducted a post hoc assessment of the effect of direct measures of forage biomass on gosling size. We did not have complete annual information on the biomass of forage species for all years when gosling growth was measured, so we conducted this post hoc analysis using the most parsimonious model from the step above to predict gosling size, then developed a set of candidate models aimed at testing for effects of biomass or biomass per capita on gosling size (Appendix 1). Biomass per capita was calculated by dividing the estimated biomass index by POPEST (above). We designed the post hoc candidate models to determine if the more direct measure of forage availability, or biomass per capita, better explained gosling size than did density. Above-ground biomass was measured at the end of July (1998-2010), which was the same period that we measured goslings at banding. The biomass index was calculated from an annual average of the above-ground biomass $\left(\mathrm{g} / \mathrm{m}^{2}\right)$ measured from grazed vegetation swards $\left(100 \mathrm{~cm}^{2}\right)$, i.e., not from an exclosure, sampled at five locations, which were within broodrearing areas on Akimiski Island. At each location, two common Canada Goose forage types were sampled in homogeneous patches: Puccinellia phryganodes and Festuca rubra and samples from each were dried to a constant weight (Hik and Jefferies 1990). For all tests where a $P$ value is presented, we considered significance at $\alpha \leq 0.05$. We did not consider variables or those models including them that were uninformative (Arnold 2010).

\section{First-year survival}

We estimated annual survival of two age groups (juvenile and adult, sexes combined) using the Brownie dead recoveries model (Brownie et al. 1985) and using program MARK (White et al. 2001). To determine fit of the global model, i.e., annually varying estimates for both age classes and the interactions for both survival probability and recovery probability, we estimated 
Table 1. Number of Canada Goose goslings that were web tagged at hatch, the number captured at banding in the same year, and the number of individual broods represented by recaptured goslings and average age at capture on Akimiski Island, Nunavut, $1993-2010$.

\begin{tabular}{|c|c|c|c|c|}
\hline Year & Goslings tagged & Goslings measured at banding & Individual broods represented & $\begin{array}{l}\text { Average age in days at banding } \\
\text { (SD) }\end{array}$ \\
\hline 1993 & 875 & 93 & 41 & $45(3)$ \\
\hline 1994 & 1272 & 164 & 78 & $45(3)$ \\
\hline 1995 & 1676 & 176 & 77 & $48(4)$ \\
\hline 1996 & 318 & 69 & 31 & $39(4)$ \\
\hline 1997 & 1470 & 148 & 78 & 44(4) \\
\hline 1998 & 981 & 68 & 32 & $47(4)$ \\
\hline 1999 & 1385 & 210 & 85 & $49(4)$ \\
\hline 2000 & 1402 & 150 & 76 & $53(4)$ \\
\hline 2001 & 932 & 100 & 54 & $51(3)$ \\
\hline 2002 & 324 & 47 & 22 & $51(4)$ \\
\hline 2003 & 715 & 51 & 21 & $47(3)$ \\
\hline 2004 & 307 & 22 & 11 & $38(3)$ \\
\hline 2005 & 1363 & 102 & 48 & $50(2)$ \\
\hline 2006 & 1345 & 43 & 18 & $50(3)$ \\
\hline 2007 & 1648 & 52 & 34 & $46(2)$ \\
\hline 2008 & 1248 & 50 & 25 & $50(4)$ \\
\hline 2009 & 545 & 31 & 16 & 41(3) \\
\hline 2010 & 513 & 35 & 21 & $51(3)$ \\
\hline
\end{tabular}

median ĉ using program MARK (White et al. 2001). We estimated survival for all goslings, those captured with web tags and those without web tags, marked at banding to bolster annual sample sizes and increase precision of survival estimates. We also modeled a trend in juvenile first-year survival and, separately, modeled the relationship between juvenile first-year survival and the annual mean size index (above). Where covariates of interest for juvenile first-year survival, i.e., size and trend, were not included in the most parsimonious model, we tested the null hypothesis that the covariates had no effect on survival (ANODEV; Grosbois et al. 2008). Where we rejected the null hypothesis, we reported the estimates for the relationships with those covariates. Survival $\left(S_{t}\right)$ is the probability that a goose alive at year $t$ was alive at year $t+$ 1 whereas recovery (f) is the probability that a goose was killed, retrieved by the hunter, and reported. Harvest rate was calculated by correcting recovery rates by dividing by band reporting rates. We used reporting rates of 0.260 for $1980-1986,0.320$ for 1987 and 1988, 0.380 from 1989-1993, 0.514 for 1994, 0.498 for 1995 , 0.491 for $1996,0.62$ for 1997, 0.805 for 1998-2001, 0.719 for 2002 , and 0.800 for 2003-2010 (see Alisauskas et al. 2009 for details). Information on hunter-killed, banded birds was provided by the Bird Banding Office of the Canadian Wildlife Service.

\section{RESULTS}

From 1993-2010, we web tagged 18,319 Canada Goose goslings at hatch and recaptured 1611 of them at an average age of 47 days posthatch ( $\mathrm{SD}=5$ days, Table 1$)$. We found significant annual variation in mean gosling size, after adjusting for age and sex of goslings and controlling for the random effect of individuals from the same brood $\left(\mathrm{F}_{17,843}=37.63, \mathrm{P}<0.001\right)$. We found a positive (but not a 1:1) relationship between mean annual hatch date and $\mathrm{NDVI}_{50}$, suggesting that Canada Geese tended to nest earlier in years of advanced plant phenology $(\beta=0.33, \mathrm{SE}=0.12, \mathrm{P}=0.004$, $\mathrm{r}^{2}=0.32$; Fig. 2). Hatching dates of individual nests varied from as early as 23 May to as late as 3 July, a range of 42 days; annual mean hatch date ranged from 29 May in 2010 to 21 June in 1996, a range of 24 days, and averaged 8 June over all years. NDVI $_{50}$ was reached as early as 10 May in 2001 and as late as 15 June in 1996, a range of 36 days. The difference between mean hatch date and $\mathrm{NDVI}_{50}$ did not change linearly over years $(\beta=0.08, \mathrm{SE}=$ $0.39, \mathrm{P}=0.850, \mathrm{r}^{2}<0.01$ ), i.e., there was no indication of a trend in plant phenology that could have potentially caused an increasing mismatch between hatch timing and plant forage availability during our study period. However, the relationship between $\mathrm{NDVI}_{50}$ and hatch timing suggests that earlier years had a larger discrepancy between mean hatch date and phenology (Appendix 2).

Fig. 2. Relationship between mean annual hatch day and an index of forage plant phenology. The dashed line represents a 1:1 relationship between hatch timing and forage plant phenology. Bars are $95 \%$ confidence limits.

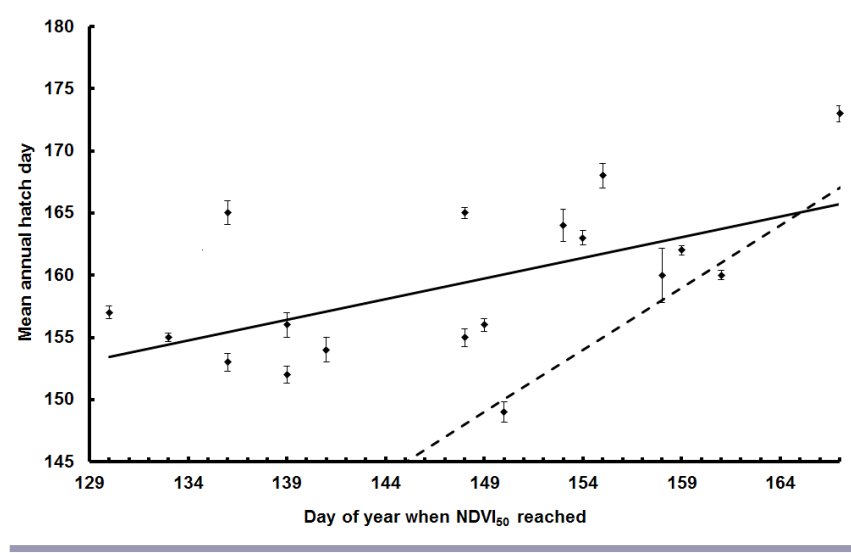

The best performing regression model describing gosling size retained the variables density, relative timing of hatch, and rainfall (Appendix 1, Table 2). Gosling size was negatively related to relative timing of hatch (Fig. 3) and to density; goslings were 
Table 2. Parameter estimates of supported models from sets of candidate models (see Appendix 1) used to assess gosling size at banding of Canada Geese hatched on Akimiski Island, NU, 1993-2010. Sets only include models with a cumulative model weight of 0.80. Variable POPEST is the number of Canada Goose pairs estimated from an annual aerial survey, and variable TIMING is the timing of hatch relative to vegetation phenology.

\begin{tabular}{|c|c|c|c|}
\hline $\mathrm{AIC}_{c} / w_{i}$ & Variable & $\beta$ estimate & Standard error \\
\hline \multicolumn{4}{|c|}{ Density and relative hatch timing } \\
\hline \multirow[t]{4}{*}{$0.00 / 0.98$} & Intercept & 34.31 & 0.635 \\
\hline & POPEST & -0.001 & $1 \times 10^{-4}$ \\
\hline & TIMING & -0.248 & 0.015 \\
\hline & June and July rain & 0.021 & 0.003 \\
\hline \multicolumn{4}{|c|}{ Post hoc analysis } \\
\hline \multirow[t]{3}{*}{$0.00 / 0.99$} & Intercept & 26.29 & 0.555 \\
\hline & TIMING & -0.299 & 0.019 \\
\hline & Biomass per capita & 3.232 & 0.260 \\
\hline
\end{tabular}

smallest in years when goose abundance on the island was largest (Fig. 4). There was also a positive relationship with total June and July rainfall. In most years, hatch tended to occur after $\mathrm{NDVI}_{50}$ was reached, but in late springs, hatch tended to coincide more closely with or before $\mathrm{NDVI}_{50}$ was reached. Four of the five best years for gosling size (1993, 2004, 2005, 2009, and 2010) occurred when hatch was early relative to vegetation phenology, and/or when the number of nesting pairs was lowest. By contrast, the five years when goslings were smallest (1994, 1998, 1999, 2001, and 2003) occurred when hatch occurred latest relative to $\mathrm{NDVI}_{50}$, and there was an above average abundance of nesting pairs observed on Akimiski Island.

Fig. 3. The relationship between gosling size at banding and hatch timing relative to forage plant phenology (after controlling for population density and total June and July rainfall) on Akimiski Island, Nunavut, from 1993-2010. Analyses were done on individual gosling size but the relationship depicted here is by mean annual size and 95\% confidence limits (bars) for clarity.

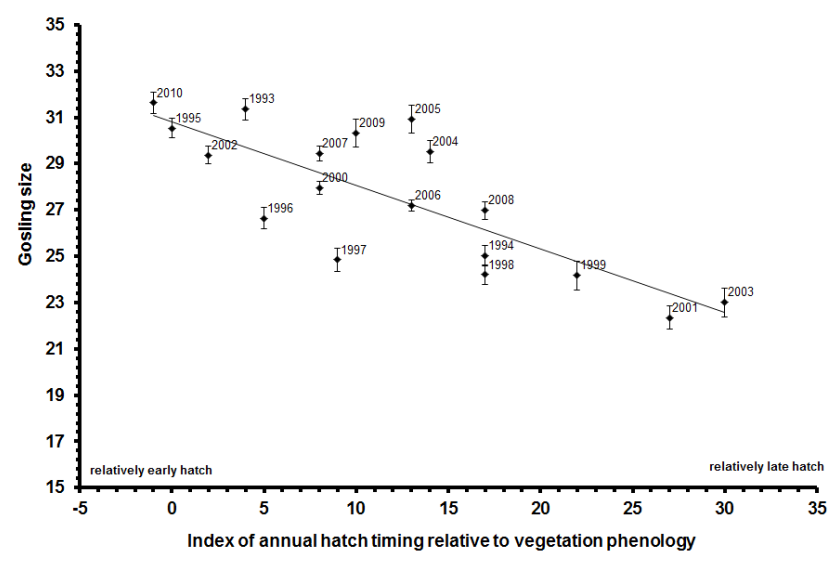

We developed a post hoc candidate model set for analysis using models to predict gosling size, which included the variables density, relative hatch timing, and June and July total rainfall as the null model. We assessed data for the subset of years in which we had biomass data available ( $\mathrm{n}=13$ years). A model, which included the variables relative timing of hatch, rainfall, and biomass per capita, included an uninformative relationship for the rainfall variable (Appendix 1). We dropped the rainfall variable and ran a reduced model, which was the most parsimonious, and included only the variables relative timing of hatch and biomass per capita (Table 2). The relationship between gosling size and relative timing was similar to the analysis above though the relationship with biomass per capita was positive (Fig. $5)$.

Fig. 4. The relationship between the annual individual gosling size (depicted as the annual means for clarity) at banding and an index of population density for Canada Geese on Akimiski Island, Nunavut (after controlling for the effect of hatch timing relative to forage plant phenology and total June and July rainfall). Gosling size was measured from 1993-2010, and population abundance is an index derived from annual aerial surveys for the same period. Bars are 95\% confidence limits.

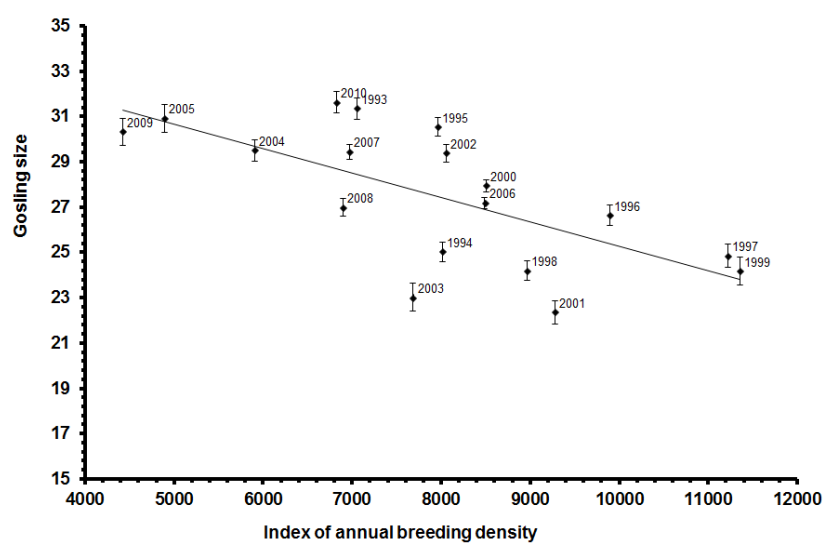

For survival analyses, we used banding data from 26,998 goslings and 18,890 adults, of which 1075 goslings were recovered dead (i. e., reported shot by hunters) in their first year, and 1655 in subsequent years; 3319 birds marked as adults were recovered dead between 1993-2012. The most parsimonious model included the variable year, and the year and age interaction, on both survival and dead recovery rates of both juveniles and adults 
(Appendix 3). This most parsimonious model, also the global model, had adequate fit $(\hat{c}=1.01, \mathrm{SE}=0.01)$. We also modelled mean annual gosling size as an annual covariate of juvenile firstyear survival $(\beta=0.18, \mathrm{SE}=0.01)$. Though the model was not competitive with the fully time-dependent model, we found that the covariate did explain significant variation $\left(\mathrm{F}_{1,10}=9.07, \mathrm{P}=\right.$ 0.02) in juvenile survival (Fig. 6). Similarly, the juvenile survival trend model $(\beta=0.11, \mathrm{SE}=0.01)$ though not competitive, was also found to explain significant variation $\left(\mathrm{F}_{1,10}=8.29, \mathrm{P}=0.020\right.$; Fig. 7) in juvenile first-year survival.

Fig. 5. The relationship between individual gosling size at banding and an annual index of per capita forage abundance (after controlling for the effects of hatch timing relative to plant phenology) on Akimiski Island, Nunavut. Goslings were measured from 1998-2010, and forage was sampled annually at five separate locations in two forage types during the same period that goslings were measured. Bars are $95 \%$ confidence limits.

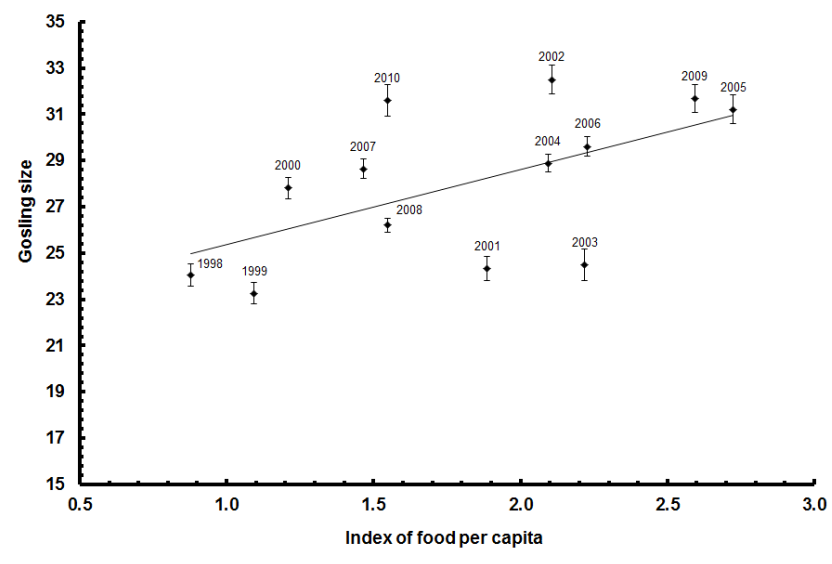

Fig. 6. The relationship between annual gosling size and annual first-year survival of Canada Geese banded on Akimiski Island, Nunavut. The gosling size covariate was found to explain significant variation in juvenile first-year survival (see text). Bars are $95 \%$ confidence limits.

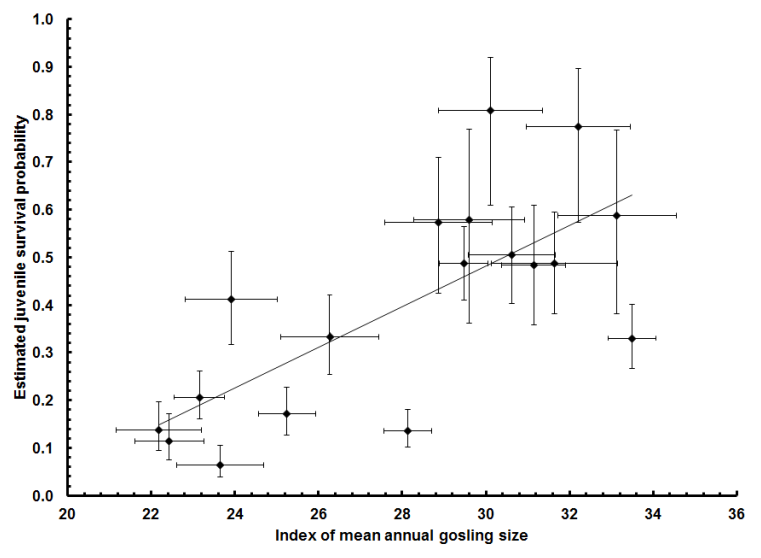

Fig. 7. Trend estimated from survival analyses for first-year survival of juvenile Canada Geese banded on Akimiski Island, Nunavut, 1993-2010. The trend variable was found to explain significant variation in juvenile first-year survival (see text). Bars are $95 \%$ confidence limits.

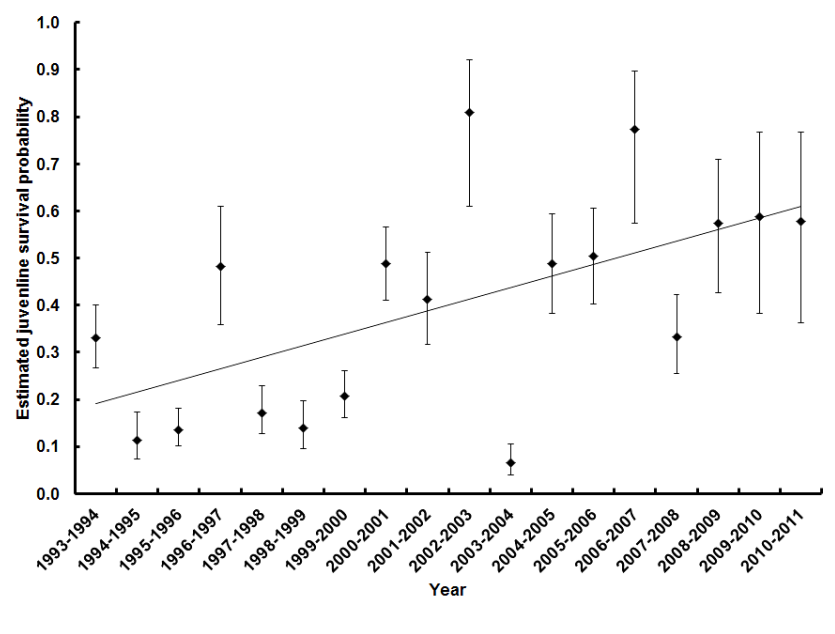

\section{DISCUSSION}

Growth of goslings on Akimiski Island was variable from year to year, and variation in growth was influenced by weather conditions, plant phenology, and goose density, all of which can affect per capita forage availability. Sedinger and Raveling (1986) suggested that timing of nesting by Arctic geese evolved to synchronize grazing by goslings and postbreeding adults with peak availability of high-quality forage plants. Forage plant quality peaks early in the growing season, when nitrogen concentrations are highest and cell wall contents are lowest, i.e., more digestible, and then declines as the season progresses (Sedinger and Raveling 1986, Manseau and Gauthier 1993). Some studies have shown that peak nitrogen concentration can precede hatch by 2-3 weeks for both Arctic (Lepage et al. 1998) and Subarctic nesting geese (Cadieux et al. 2005). Although Canada Geese on Akimiski Island appeared to track plant phenology, i. e., there was a positive correlation between date of hatch and $\mathrm{NDVI}_{50}$, they often did not initiate nests early enough to fully keep pace with advanced plant phenology in early springs (i.e., not a perfect or 1:1 correlation) suggesting a potential mismatch (Clausen and Clausen 2013). Similarly, plant phenology advanced more quickly than did nest initiation timing by Greater Snow Geese (Chen caerulescens atlantica) during early springs in the High Arctic (Dickey et al. 2008). As a result, hatch dates of Subarctic and Arctic nesting geese often may be later than is optimal compared to peak availability of high quality food, a finding that is not uncommon in birds (Drent 2006). Our results suggest that hatching late relative to $\mathrm{NDVI}_{50}$ has a negative effect on gosling growth, and this effect occurred most often when spring was earlier than average relative to calendar date.

Raveling (1978) suggested that follicular development in Subarctic nesting Canada Geese began at about the same time that they left their final spring staging areas for the short flight 
(1-2 days) before arrival on nesting areas, because there was often a delay of 9-12 days after arrival before egg laying began, even when nesting areas were suitable for nesting upon arrival (Raveling and Lumsden 1977). Raveling (1978) also suggested that ovulation could be inhibited when appropriate proximate factors were lacking, and several studies of geese have noted that delayed nesting was associated with delayed migration, extensive snow cover or lack of available nest sites, and lower than average temperatures (Barry 1962, Raveling and Lumsden 1977, Reed et al. 2004, Dickey et al. 2008). In 2010, the earliest year of nesting in our study, mean hatch date was 29 May and roughly coincided with $\mathrm{NDVI}_{50}$ that year, suggesting that Canada Geese are physiologically capable of responding to earlier springs depending on conditions to the south.

Compared to the nearby mainland at the same latitude, Akimiski Island is anomalously cold because of prolonged exposure to the sea ice of James Bay (Martini and Glooschenko 1984). Leafloor et al. (1998) collected eggs from nests on Akimiski Island and from mainland nesting areas near Kinoje Lake, about $200 \mathrm{~km}$ to the south, and artificially incubated the eggs until hatching. Canada Geese from both areas share common migration and wintering areas, and despite their proximity, 32 of 35 eggs from mainland nests hatched before any eggs from Akimiski Island hatched. On average, eggs from mainland nests hatched six days earlier than those from the island (Leafloor et al. 1998) suggesting that cues for initiation of nesting are localized and specific to the nesting area.

Dickey et al. (2008) suggested that reduced growth of Greater Snow Goose goslings in warm early springs could have been a result of a mistiming of hatch relative to the peak in food quality or because of density-dependent effects, but it was not possible to disentangle these effects (but see Doiron 2014). Early spring relative to calendar date can lead to an advance in plant phenology (Schwartz et al. 2006, Doiron et al. 2013) and also can increase nesting propensity and success in geese (Reed et al. 2004), whereas late springs have the opposite effect on nesting propensity and success (Barry 1962). Thus, the effects of climate are often correlated with changes in brood density as well as with the quality and availability of forage plants and timing of plant phenology. As a result, we found reduced gosling growth rates in some years of early spring phenology because numbers of nesting pairs, and broods, increased, and hatch tended to occur late relative to plant phenology. By contrast, gosling growth rates were highest in years with low nesting Canada Goose abundance, which occurred more in late springs. In these years, hatch dates also tended to coincide more closely with $\mathrm{NDVI}_{50}$. However, the relationship between per capita forage availability and gosling size, and that between gosling size and first-year survival of prefledging goslings between 1998 and 2010, led us to infer that density-dependent effects must have been more intense in the years preceding our study (Fig. 1), when the population of Canada Geese was much higher than during our study period (see Fig. 5).

Coastal marshes on the north shore of Akimiski Island constitute the most important brood rearing habitat for geese. In the late 1970s, these coastal marshes were dominated by Puccinellia phryganodes and Carex subspathacea (Martini and Glooschenko 1984, Jefferies et al. 2006), both of which are high quality forage plants for geese (Gadallah and Jefferies 1995a, b). However, these coastal habitats have been progressively degraded over time by the foraging activities of large numbers of staging and nesting geese, and habitat loss was most pronounced from 1985-1993, when more than 5000 ha of coastal marsh were lost on Akimiski Island (Jefferies et al. 2006). Based on the decline in harvest rates of juvenile Canada Geese, we hypothesize that the goose-habitat relationship on Akimiski Island reached a tipping point starting in about 1986, presumably because abundance of Canada Geese and their broods exceeded carrying capacity of brood rearing areas, which led to declines in gosling growth and postfledging survival. Habitat loss may have continued through 2000 (Jefferies et al. 2006), and although some forage species increased in abundance between 1998-2008, the magnitude of changes was small, and above-ground biomass remained low (Kotanen and Abraham 2013). Despite this, we found that first-year survival rates of Canada Geese increased over the course of our study, and increased survival was associated with increases in gosling size. We attribute the increase in gosling size to increases in per capita forage caused by the overall decline in abundance of nesting Canada Geese. The 1990-2010 annual decline was about 585 breeding Canada Geese per year: linear regression with a log link $P<0.0001$. As abundance declined, growth rates and postfledging first-year survival increased in most years since 2000. A notable exception was 2003, which may be explained by the highest index of annual hatch timing relative to plant phenology observed during our study.

Overall, our results support previous studies that suggested forage availability is directly linked to components of population dynamics through density-dependent effects on gosling growth and first-year survival in geese (Sedinger et al. 2001, Sedinger and Nicolai 2011). We found that timing of breeding relative to plant phenology also affects gosling growth adding to our understanding of potential consequences of increasingly variable climatic conditions (Visser 2008). Monitoring the effects of potentially increasing stochasticity or system change on the population dynamics of Arctic and Subarctic breeding geese may be important for future management of these harvested species.

\section{Responses to this article can be read online at:} http://www.ace-eco.org/issues/responses.php/708

\section{Acknowledgments:}

We thank the staff at the Ontario Ministry of Natural Resources and the many people who helped collect the data over many years. The Vegetation Index and Phenology Lab, University of Arizona (http://vip.arizona.edu) provided the daily mosaics of global MODIS NDVI data. We thank Lise Aubry and two anonymous reviewers for comments that helped to improve the manuscript. We also thank David Koons for his helpful suggestions for the survival analyses. Funding was provided by the Mississippi and Atlantic Flyway councils, Arctic Goose Joint Venture to the Hudson Bay Project, Ontario Ministry of Natural Resources, and the Canadian Wildlife Service. Animal care permits were provided by the Ontario Ministry of Natural Resources animal care committee annually. Annual wildlife research permits were provided by the Government of Nunavut. The Canadian Wildlife Service provided annual permits for banding and to conduct research in the Akimiski Island bird sanctuary. The government of Nunavut provided annual wildlife 
research permits. Use of trade names does not imply endorsement by the U.S. Government.

\section{LITERATURE CITED}

Alisauskas, R. T., K. L. Drake, and J. D. Nichols. 2009. Filling a void: abundance estimation of North American populations of Arctic geese using hunter recoveries. Pages 463-489 in D. L. Thompson, E. G. Cooch, and M. J. Conroy, editors. Modeling demographic processes in marked populations. Environmental and Ecological Statistics. Vol. 3. Springer, New York, New York, USA. http://dx.doi.org/10.1007/978-0-387-78151-8_20

Arnold, T. W. 2010. Uninformative parameters and model selection using Akaike's information criterion. Journal of Wildlife Management 74:1175-1178. http://dx.doi.org/10.1111/j.1937-2817.2010. tb01236.x

Barry, T. W. 1962. Effect of late seasons on Atlantic Brant reproduction. Journal of Wildlife Management 26:19-26. http:// dx.doi.org/10.2307/3798163

Bazely, D. R., and R. L. Jefferies. 1986. Changes in the composition and standing crop of salt-marsh communities in response to removal of a grazer. Journal of Ecology 74:693-706. http://dx.doi.org/10.2307/2260392

Bazely, D. R., and R. L. Jefferies. 1989. Leaf and shoot demography of an Arctic stoloniferous grass, Puccinellia phryganodes, in response to grazing. Journal of Ecology 77:811-822. http://dx.doi.org/10.2307/2260987

Bazely, D. R., and R. L. Jefferies. 1997. Trophic interactions in Arctic ecosystems and the occurrence of a terrestrial trophic cascade. Pages 183-207 in S. J. Woodin and M. Marquiss, editors. Ecology of Arctic environments. British Ecological Society, London, UK.

Brownie, C., D. R. Anderson, K. P. Burnham, and D. S. Robson. 1985. Statistical inference from band recovery data: a handbook. Second edition. U. S. Fish and Wildlife Service, Washington, D. C., USA.

Burnham, K. P., and D. R. Anderson. 2002. Model selection and multimodel inference: a practical information-theoretic approach. Second edition. Springer-Verlag, New York, New York, USA.

Cadieux, M.-C., G. Gauthier, and R. J. Hughes. 2005. Feeding ecology of Canada Geese (Branta canadensis interior) in Subarctic inland tundra during brood rearing. Auk 122:144-157. http://dx.doi.org/10.1642/0004-8038(2005)122[0144:FEOCGB]2.0. $\mathrm{CO} ; 2$

Cargill, S. M., and R. L. Jefferies. 1984. The effects of grazing by Lesser Snow Geese on the vegetation of a Sub-arctic salt marsh. Journal of Applied Ecology 21:669-686. http://dx.doi. org/10.2307/2403437

Clausen, K. K., and P. Clausen. 2013. Earlier Arctic springs cause phenological mismatch in long-distance migrants. Oecologia 173:1101-1112. http://dx.doi.org/10.1007/s00442-013-2681-0

Cleland, E. E., J. M. Allen, T. M. Crimmins, J. A. Dunne, S. Pau, S. E. Travers, E. S. Zavaleta, and E. M. Wolkovich. 2012. Phenological tracking enables positive species responses to climate change. Ecology 93:1765-1771. http://dx.doi. org/10.1890/11-1912.1
Cooch, E. G., D. B. Lank, A. Dzubin, R. F. Rockwell, and F. Cooke. 1991a. Body size variation in Lesser Snow Geese: environmental plasticity in gosling growth rates. Ecology 72:503-512. http://dx.doi.org/10.2307/2937191

Cooch, E. G., D. B. Lank, R. F. Rockwell, and F. Cooke. $1991 b$. Long-term decline in body size in a Snow Goose population: evidence of environmental degradation? Journal of Animal Ecology 60:483-496. http://dx.doi.org/10.2307/5293

Cooch, E. G., R. F. Rockwell, and S. Brault. 2001. Retrospective analysis of demographic response to environmental change: a Lesser Snow Goose example. Ecological Monographs 71:377-400. http://dx.doi.org/10.1890/0012-9615(2001)071[0377:RAODRT]2.0. $\mathrm{CO} ; 2$

Dickey, M.-H., G. Gauthier, and M.-C. Cadieux. 2008. Climatic effects on the breeding phenology and reproductive success of an Arctic-nesting goose species. Global Change Biology 14:1973-1985. http://dx.doi.org/10.1111/j.1365-2486.2008.01622.x

Doiron, M. 2014. Impacts des changements climatiques sur les relations plantes-herbivores dans l'Arctique. Dissertation. Université Laval, Québec, Québec, Canada.

Doiron, M., P. Legagneux, G. Gauthier, and E. Lévesque. 2013. Broad-scale satellite normalized difference vegetation index data predict plant biomass and peak date of nitrogen concentration in Arctic tundra vegetation. Applied Vegetation Science 16:343-351. http://dx.doi.org/10.1111/j.1654-109X.2012.01219.x

Donnelly, A., A. Caffarra, and B. F. O'Neill. 2011. A review of climate-driven mismatches between interdependent phenophases in terrestrial and aquatic ecosystems. International Journal of Biometeorology 55:805-817. http://dx.doi.org/10.1007/s00484-011-0426-5

Drent, R. H. 2006. The timing of birds' breeding season: the Perrins hypothesis revisited especially for migrants. Ardea 94:305-322.

Dunn, P. O., D. W. Winkler, L. A. Whittingham, S. J. Hannon, and R. J. Robertson. 2011. A test of the mismatch hypothesis: how is timing of reproduction related to food abundance in an aerial insectivore? Ecology 92:450-461. http://dx.doi.

org/10.1890/10-0478.1

Dzubin, A., and E. G. Cooch. 1992. Measurements of geese: general field methods. California Waterfowl Association, Sacramento, California, USA.

Fondell, T. F., P. L. Flint, J. S. Sedinger, C. A. Nicolai, and J. L. Schamber. 2011. Intercolony variation in growth of Black Brant goslings in the Yukon-Kuskokwim delta, Alaska. Journal of Wildlife Management 75:101-108. http://dx.doi.org/10.1002/ jwmg. 24

Gadallah, F. L., and R. L. Jefferies. 1995a. Comparison of the nutrient contents of the principal forage plants utilized by Lesser Snow Geese on summer breeding grounds. Journal of Applied Ecology 32:263-275. http://dx.doi.org/10.2307/2405094

Gadallah, F. L., and R. L. Jefferies. 1995b. Forage quality in brood rearing areas of the Lesser Snow Goose and the growth of captive goslings. Journal of Applied Ecology 32:276-287. http://dx.doi. org/10.2307/2405095

Grosbois, V., O. Gimenez, J.-M. Gaillard, R. Pradel, C. Barbraud, J. Clobert, A. P. Møller, and H. Weimerskirch. 2008. Assessing 
the impact of climate variation on survival in vertebrate populations. Biological Review 83:357-399. http://dx.doi. org/10.1111/j.1469-185X.2008.00047.x

Harwood, J. 1977. Summer feeding ecology of Lesser Snow Geese. Journal of Wildlife Management 41:48-55. http://dx.doi. org/10.2307/3800089

Hik, D. S., and R. L. Jefferies. 1990. Increases in the net aboveground primary production of a salt-marsh forage grass: a test of the predictions of the herbivore-optimization model. Journal of Ecology 78:180-195. http://dx.doi.org/10.2307/2261044

Hill, M. R. J., R. T. Alisauskas, C. D. Ankney, and J. O. Leafloor. 2003. Influence of body size and condition on harvest and survival of juvenile Canada Geese. Journal of Wildlife Management 67:530-541. http://dx.doi.org/10.2307/3802711

Holben, B. N. 1986. Characteristics of maximum-value composite images from temporal AVHRR data. International Journal of Remote Sensing 7:1417-1434. http://dx.doi. org/10.1080/01431168608948945

Jefferies, R. L., A. P. Jano, and K. F. Abraham. 2006. A biotic agent promotes large-scale catastrophic change in the coastal marshes of Hudson Bay. Journal of Ecology 94:234-242. http:// dx.doi.org/10.1111/j.1365-2745.2005.01086.x

Kalnay, E., M. Kanamitsu, R. Kistler, W. Collins, D. Deaven, L. Gandin, M. Iredell, S. Saha, G. White, J. Woollen, Y. Zhu, A. Leetmaa, R. Reynolds, M. Chelliah, W. Ebisuzaki, W. Higgins, J. Janowiak, K. C. Mo, C. Ropelewski, J. Wang, R. Jenne, and D. Joseph. 1996. The NCEP/NCAR 40-year reanalysis project. Bulletin of the American Meteorological Society 77:437-470. http://dx.doi.org/10.1175/1520-0477(1996)077<0437:TNYRP>2.0. $\mathrm{CO} ; 2$

Kotanen, P. M., and K. F. Abraham. 2013. Decadal changes in vegetation of a Subarctic salt marsh used by Lesser Snow and Canada Geese. Plant Ecology 214:409-422. http://dx.doi. org/10.1007/s11258-013-0178-X

Kuijper, D. P. J., R. Ubels, and M. J. J. E. Loonen. 2009. Densitydependent switches in diet: a likely mechanism for negative feedbacks on goose population increase? Polar Biology 32:1789-1803. http://dx.doi.org/10.1007/s00300-009-0678-2

Lake, B. C., J. A. Schmutz, M. S. Lindberg, C. R. Ely, W. D. Eldridge, and F. J. Broerman. 2008. Body mass of prefledging Emperor Geese Chen canagica: large-scale effects of interspecific densities and food availability. Ibis 150:527-540. http://dx.doi. org/10.1111/j.1474-919X.2008.00814.X

Leafloor, J. O., K. F. Abraham, D. H. Rusch, R. K. Ross, and M. R. J. Hill. 1996. Status of the Southern James Bay population of Canada Geese. Pages 103-108 in J. T. Ratti, editor. Proceedings of the 7th international waterfowl symposium. Memphis, Tennessee, USA.

Leafloor, J. O., C. D. Ankney, and D. H. Rusch. 1998. Environmental effects on body size of Canada Geese. Auk 115:26-33. http://dx.doi.org/10.2307/4089108

Leafloor, J. O., M. R. J. Hill, D. H. Rusch, K. F. Abraham, and R. K. Ross. 2000. Nesting ecology and gosling survival of Canada Geese on Akimiski Island, Nunavut. Pages 109-116 in K. M. Dickson, editor. Towards conservation of the diversity of Canada
Geese (Branta canadensis). Canadian Wildlife Service Occasional Paper, No. 103. Canadian Wildlife Service, Ottawa, Ontario, Canada.

Leafloor, J. O., and D. H. Rusch. 1997. Clinal size variation in Canada Geese: implication for the use of morphometric discrimination techniques. Journal of Wildlife Management 61:183-190. http://dx.doi.org/10.2307/3802427

Lepage, D., G. Gauthier, and A. Reed. 1998. Seasonal variation in growth of Greater Snow Goose goslings: the role of food supply. Oecologia 114:226-235. http://dx.doi.org/10.1007/ s004420050440

Lindholm, A., G. Gauthier, and A. Desrochers. 1994. Effect of hatch date and food supply on gosling growth in Arctic-nesting Greater Snow Geese. Condor 96:898-908. http://dx.doi. org/10.2307/1369100

Loonen, M. J. J. E., K. Oosterbeek, and R. H. Drent. 1997. Variation in growth of young and adult size in Barnacle Geese Branta leucopsis: evidence for density dependence. Ardea 85:177-192.

Manseau, M., and G. Gauthier. 1993. Interactions between Greater Snow Geese and their rearing habitat. Ecology 74:2045-2055. http://dx.doi.org/10.2307/1940850

Martini, I. P., and W. A. Glooschenko. 1984. Emergent coasts of Akimiski Island, James Bay, Northwestern Territories, Canada: geology, geomorphology, and vegetation. Sedimentary Geology 37:229-250. http://dx.doi.org/10.1016/0037-0738(84)90016-2

Miura, T., A. Huete, and H. Yoshioka. 2006. An empirical investigation of cross-sensor relationships of NDVI and red/nearinfrared reflectance using EO-1 Hyperion data. Remote Sensing of Environment 100:223-236. http://dx.doi.org/10.1016/j.rse.2005.10.010

Mowbray, T. B., C. R. Ely, J. S. Sedinger, and R. E. Trost. 2002. Canada Goose (Branta canadensis). In A. Poole and F. Gill, editors. The birds of North America, no. 681. Academy of Natural Sciences, Philadelphia, Illinois, USA and American Ornithologists' Union, Washington, D.C., USA.

Nicolai, C. A., J. S. Sedinger, D. H. Ward, and W. S. Boyd. 2014. Spatial variation in life-history trade-offs results in an ideal free distribution in Black Brant Geese. Ecology 95:1323-1331. http:// dx.doi.org/10.1890/13-0860.1

Patton, K. A. 2001. The effect of body mass and size on late summer survival of Canada Goose (Branta canadensis interior) goslings on Akimiski Island, Nunavut. Thesis. University of Western Ontario, London, Ontario, Canada.

Person, B. T. 2001. Herbivore-mediated effects on ecosystem processes in a near-arctic salt marsh. Dissertation. University of Alaska, Fairbanks, Alaska, USA.

Person, B. T., M. P. Herzog, R. W. Ruess, J. S. Sedinger, R. M. Anthony, and C. A. Babcock. 2003. Feedback dynamics of grazing lawns: coupling vegetation change with animal growth. Oecologia 135:583-592. http://dx.doi.org/10.1007/s00442-003-1197-4

Raveling, D., and H. G. Lumsden. 1977. Nesting ecology of Canada Geese in the Hudson Bay Lowlands of Ontario: evolution and population regulation. Fish and Wildlife Research Report No. 98. Ontario Ministry of Natural Resources, Toronto, Ontario, Canada. 
Raveling, D. 1978. The timing of egg laying by northern geese. Auk 95:294-303.

Reed, E., G. Gauthier, and J.-F. Giroux. 2004. Effects of spring conditions on breeding propensity of Greater Snow Goose females. Animal Biodiversity and Conservation 27:35-46.

Ryan, S. J., P. C. Cross, J. Winnie, C. Hay, J. Bowers, and W. M. Getz. 2012. The utility of normalized difference vegetation index for predicting African buffalo forage quality. Journal of Wildlife Management 76:1499-1508. http://dx.doi.org/10.1002/jwmg.407

Saino, N., R. Ambrosini, D. Rubolini, J. von Hardenberg, A. Provenzale, K. Hüppop, O. Hüppop, A. Lehikoinen, E. Lehikoinen, K. Rainio, M. Romano, and L. Sokolov. 2011. Climate warming, ecological mismatch at arrival and population decline in migratory birds. Proceeding of the Royal Society B 278:835-842. http://dx.doi.org/10.1098/rspb.2010.1778

SAS Institute. 2003. SAS/STATR user's guide. Second Edition. Version 9.2. SAS Institute, Cary, North Carolina, USA. [online] URL: http://support.sas.com/documentation/cdl/en/statug/63033/ PDF/default/statug.pdf

Schmutz, J. A. 1993. Survival and pre-fledging body mass in juvenile Emperor Geese. Condor 95:222-225. http://dx.doi. org/10.2307/1369404

Schmutz, J. A., and K. K. Laing. 2002. Variation in foraging behavior and body mass in broods of Emperor Geese (Chen canagica): evidence for interspecific density dependence. Auk 119:996-1009. http://dx.doi.org/10.1642/0004-8038(2002)119[0996: VIFBAB]2.0.CO;2

Schmutz, J. A., B. F. Manly, and C. P. Dau. 2001. Effects of gull predation and weather on survival of Emperor Goose goslings. Journal of Wildlife Management 65:248-257. http://dx.doi. org/10.2307/3802904

Schwartz, M. D., R. Ahas, and A. Aasa. 2006. Onset of spring starting earlier across the Northern Hemisphere. Global Change Biology 12:343-351. http://dx.doi.org/10.1111/j.1365-2486.2005.01097. $\mathrm{x}$

Sedinger, J. S., and N. D. Chelgren. 2007. Survival and breeding advantages of larger Black Brant (Branta bernicla nigricans) goslings: within- and among-cohort variation. Auk 124:1281-1293. http://dx.doi.org/10.1642/0004-8038(2007)124[1281:SABAOL]2.0. $\mathrm{CO} ; 2$

Sedinger, J. S., and D. G. Raveling. 1986. Timing of nesting by Cackling Canada Geese in relation to the quality and availability of their food plants. Journal of Animal Ecology 55:1083-1102. http://dx.doi.org/10.2307/4435

Sedinger, J. S., and P. L. Flint. 1991. Growth rate is negatively correlated with hatch date in Black Brant. Ecology 72:496-502. http://dx.doi.org/10.2307/2937190

Sedinger, J. S., P. L. Flint, and M. S. Lindberg. 1995. Environmental influence on life-history traits: growth, survival, and fecundity in Black Brant (Branta bernicla). Ecology 76:2404-2414. http://dx.doi.org/10.2307/2265816

Sedinger, J. S., M. P. Herzog, B. T. Person, M. T. Kirk, T. Obritchkewitch, P. P. Martin, and A. A. Stickney. 2001. Largescale variation in growth of Black Brant goslings related to food availability. Auk 118:1088-1095. http://dx.doi.org/10.1642/0004-8038 (2001)118[1088:LSVIGO]2.0.CO;2

Sedinger, J. S., M. S. Lindberg, B. T. Person, M. W. Eichholz, M. Herzog, and P. L. Flint. 1998. Density dependent effects on growth, body size and clutch size in Black Brant. Auk 115:613-620. http://dx.doi.org/10.2307/4089410

Sedinger, J. S., and C. A. Nicolai. 2011. Recent trends in first-year survival for Black Brant breeding in southwestern Alaska. Condor 113:511-517. http://dx.doi.org/10.1525/cond.2011.100218

Shorrocks, B., S. Albon, H. P. van der Juegd, and K. Larsson. 1998. Pre-breeding survival of Barnacle Geese Branta leucopsis in relation to fledging characteristics. Journal of Animal Ecology 67:953-966. http://dx.doi.org/10.1046/j.1365-2656.1998.6760953. $\mathrm{x}$

Stenseth, N. C., and A. Mysterud. 2002. Climate, changing phenology, and other life-history traits: non-linearity and matchmismatch to the environment. Proceedings of the National Academy of Sciences 99:13379-13381. http://dx.doi.org/10.1073/ pnas. 212519399

Tucker, C. J. 1979. Red and photographic infrared linear combinations for monitoring vegetation. Remote Sensing of Environment 8:127-150. http://dx.doi.org/10.1016/0034-4257(79) 90013-0

Visser, M. E. 2008. Keeping up with a warming world; assessing the rate of adaptation to climate change. Proceedings of the Royal Society B 275:649-659. http://dx.doi.org/10.1098/rspb.2007.0997

Visser, M. E., and C. Both. 2005. Shifts in phenology due to global climate change: the need for a yardstick. Proceedings of the Royal Society B 272:2561-2569. http://dx.doi.org/10.1098/rspb.2005.3356

Walter, S. E., and D. H. Rusch. 1997. Accuracy of egg flotation in determining age of Canada Goose nests. Wildlife Society Bulletin 25:854-857.

White, G. C., K. P. Burnham, and D. R. Anderson. 2001. Advanced features of Program Mark. Wildlife, land, and people: priorities for the 21st century. Pages 368-377 in R. Field, R. J. Warren, H. Okarma, and P. R. Sievert, editors. Proceedings of the second international wildlife management congress. Wildlife Society, Bethesda, Maryland, USA.

Williams, T. D., E. G. Cooch, R. L. Jefferies, and F. Cooke. 1993. Environmental degradation, food limitation and reproductive output: juvenile survival in Lesser Snow Geese. Journal of Animal Ecology 62:766-777. http://dx.doi.org/10.2307/5395
Editor-in-Chief: Keith A.Hobson

Subject Editor: Gilles Gauthier
Sponsored by the Society of Canadian Ornithologists and Bird Studies Canada Parrainée par la Société des ornithologistes du Canada et Etudes d'oiseaux Canada

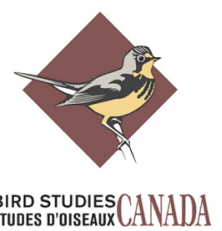


Appendix 1. Candidate models used to evaluate gosling size at banding.

Table A1.1. List of candidate models used to evaluate gosling size at banding for Canada geese nesting on Akimiski Island, NU. All models included the random effect of brood ID. Analyses are based on 1611 measured known aged goslings. See Methods for explanation of covariates.

\begin{tabular}{|c|c|c|c|c|}
\hline Model details & $\Delta \mathrm{AIC}_{\mathrm{c}}{ }^{1}$ & $\mathrm{~W}_{\mathrm{i}}$ & $-2 \mathrm{LL}$ & $\mathrm{NP}^{2}$ \\
\hline POPEST + TIMING + Rain & 0.00 & 0.98 & 9699.69 & 4 \\
\hline POPEST + TIMING ${ }^{2}$ + Rain & 7.70 & 0.02 & 9707.39 & 5 \\
\hline POPEST + TIMING & 53.60 & 0.00 & 9753.29 & 3 \\
\hline POPEST + TIMING ${ }^{2}$ & 63.08 & 0.00 & 9762.76 & 4 \\
\hline POPEST + TIMING + & 63.34 & 0.00 & 9763.03 & 4 \\
\hline \multicolumn{5}{|l|}{ SUCCNESTS } \\
\hline SUCCNESTS + TIMING + Rain & 151.51 & 0.00 & 9851.20 & 4 \\
\hline TIMING & 165.90 & 0.00 & 9865.58 & 2 \\
\hline TIMING $^{2}$ & 174.30 & 0.00 & 9873.98 & 3 \\
\hline SUCCNESTS + TIMING & 176.56 & 0.00 & 9876.24 & 3 \\
\hline POPEST & 266.47 & 0.00 & 9966.16 & 2 \\
\hline Rain & 470.50 & 0.00 & 10170.19 & 2 \\
\hline Null (intercept only) & 471.04 & 0.00 & 10170.72 & 1 \\
\hline
\end{tabular}

Post Hoc analysis (1998 - 2010)

TIMING + Biomass per capita

0.00

0.99

5719.42

3

TIMING + Rain + Biomass per

8.83

0.01

5728.25

3 
capita

POPEST + TIMING + Rain +

27.25

0.00

5746.68

5

grazed biomass

Null (POPEST + TIMING + Rain)

57.11

0.00

5776.53

4

POPEST + TIMING

59.03

0.00

5778.46

3

1. $\triangle \mathrm{AIC}_{\mathrm{c}}$ is the difference in Akaike's Information Criterion between the best model and the model in question. $W_{i}$ is the Akaike's weight and LL is the Log Likelihood.

2. Number of estimated paramters 
Appendix 2. Relationship between the day of year when the $\mathrm{NDVI}_{50}$ was reached and an index of hatch timing.

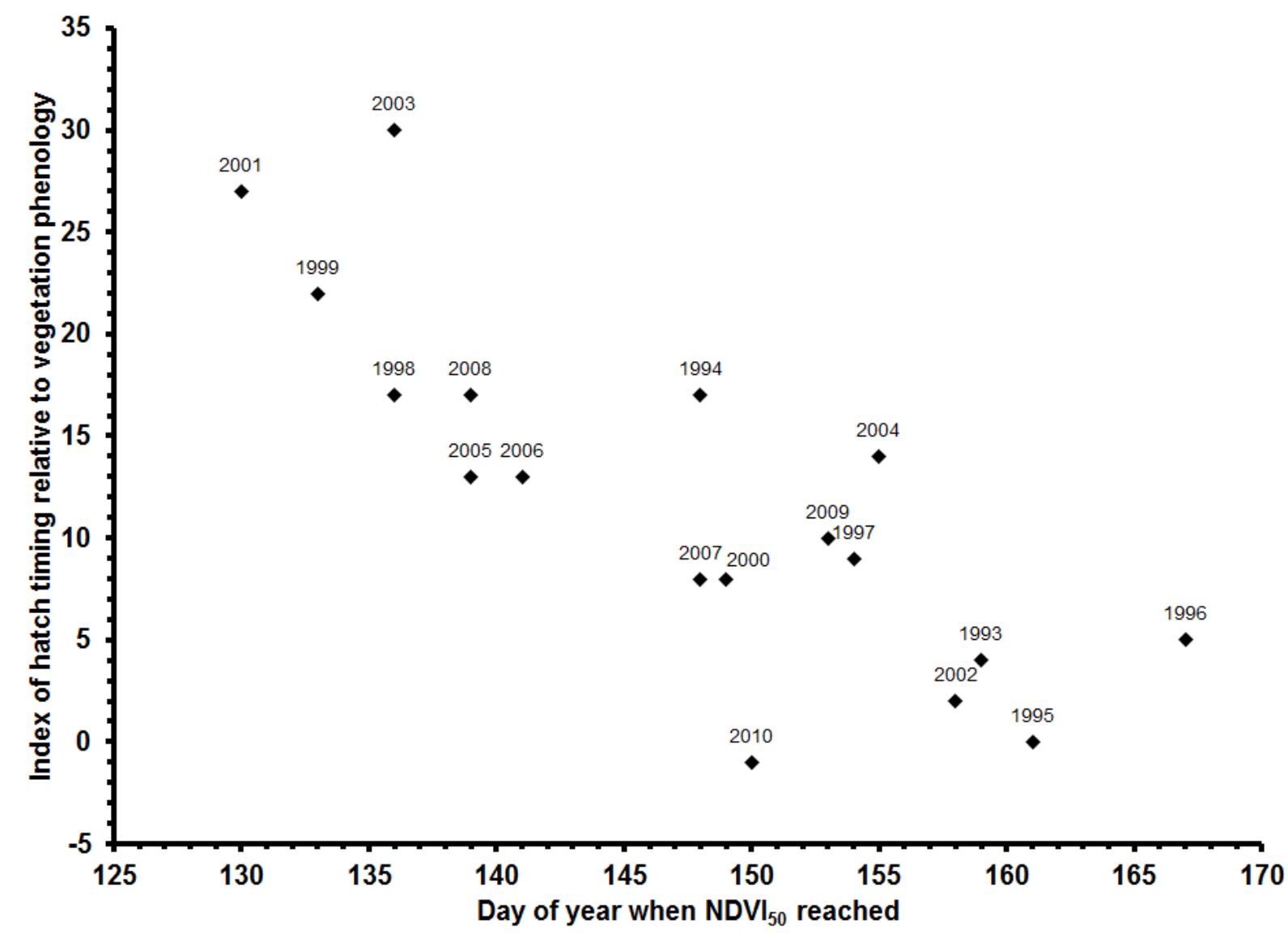

Fig. A2.1. Relationship between the day of year when the $\mathrm{NDVI}_{50}$ was reached and an index of hatch timing relative to forage plant phenology for Canada geese on Akimiski Island, NU, from 1993 to 2010. 
Appendix 3. Survival candidate models.

Table. A3.1. Candidate models describing survival probability of juvenile (Juv) and adult Canada geese banded on Akimiski Island, NU, 1993 to 2010, using the Brownie et al. (1985) parameterization and ranked by Akaike's Information Criterion corrected for small sample sizes $\left(\mathrm{AIC}_{\mathrm{c}}\right)$. Recovery probability was the same for all models (age groups with independent annual estimates).

Survival Model Parameterization

Juv: year, Adult: year (age groups independent)

Juv: year, Adult: constant

Juv: size, Adult: constant

Juv: trend, Adult: constant

Juv: constant, Adult: constant

${ }^{1}$ Number of estimated parameters
$\mathrm{AIC}_{\mathrm{c}} \quad \Delta \mathrm{AIC}_{\mathrm{c}} \quad \mathrm{NP}^{1}$

$\begin{array}{lll}56010.6 & 0.00 \quad 74\end{array}$

$\begin{array}{lll}56019.6 & 9.02 \quad 57\end{array}$

$\begin{array}{lll}56253.7 & 243.06 & 41\end{array}$

$56376.9 \quad 366.27 \quad 41$

$56492.9 \quad 482.36 \quad 40$ 